Furthermore, secondary prevention in HIV infected injecting drug misusers aims at another aspect: socially reintegrated patients or those enrolled in a drug treatment programme are more likely to attend educational programmes, which may limit the further spread of HIV infection. ${ }^{4617}$

We thank the staff of the methadone treatment services (Department of Social Psychiatry, Psychiatric University Hospital, University Hospital, Zurich; chairman: Professor A Uchtenhagen) for patient care and $\mathrm{K}$ Olsson for technical help. This work was supported in part by a grant from the Swiss Federal Office of Public Health.

1 Goedert JJ, Blattner WA. The epidemiology and natural history of huma immunodeficiency virus. In: De Vita VT, Hellman S, Rosenberg SA, eds. AIDS: etiology, diagnosis, treatment, and prevention. Philadelphia: Lippincott, AIDS: etiolo

2 Centers for Disease Control. Revision of the case definition for acquired immunodeficiency syndrome. MMWR 1987;36(suppl 2S):1-15S.

3 Des Jarlais DC, Friedman SR, Novick DM, et al. HIV-1 infection among intravenous drug users in Manhattan, New York City, from 1977 through 1987. FAMA 1989;261:1008-12.

4 Brickner PW, Torres RA, Barnes M, et al. Recommendations for control and prevention of human immunodeficiency virus (HIV) infection in intravenous drug users. Ann Intern Med 1989;110:833-7.

5 Centers for Disease Control. Coordinated community programs for HIV prevention among intravenous drug users-California, Massachussetts. MMWR 1989;38:369-74.

6 Cooper JR. Methadone treatment and acquired immunodeficiency syndrome. FAMA 1989;262:1664-8.

7 Goedert JJ, Biggar RJ, Melby M, et al. Effect of T4 count and cofactor on the incidence of AIDS or AIDS related condition: three year follow up of the San incidence of AIDS or AIDS related condition: three year foll

8 De Wolf F, Lange JMA, Houwelling TM, et al. Numbers of CD4+ cells and the levels of core antigen of and antibodies to the human immunodeficiency
virus as predictors of AIDS among seropositive homosexual men. F Infect Dis virus as predictors
$1988 ; 158: 615-22$
9 Des Jarlais DC, Friedman SR, Marmor M, et al. Development of AIDS, HIV seroconversion, and potential co-factors for $\mathrm{T} 4$ cell loss in a cohort of intravenous drug users. AIDS 1987;1:105-11.

10 Kaslow AR, Blackwelder WC, Ostrow DG, et al. No evidence for a role of alcohol or other psychoactive drugs in accelerating immunodeficiency in HIV-1-positive individuals. FAMA 1989;261:3424-9.

11 Zagury D, Bernard J, Leonard R, et al. Long-term cultures of HTLV-IIIinfected cells: a model of cytopathology of T-cell depletion in AIDS. Science infected cells: a

12 Skolnik PR, Kosloff BR, Hirsch MS. Bidirectional interactions between human immunodeficiency virus type 1 and cytomegalovirus. $\mathcal{F}$ Infect Dis human immunodefic

13 Davis MG, Kenney SC, Kamine J, Pagano JS, Huang ES. Immediate-early gene region of human cytomegalovirus transactivates the promoter of human immunodeficiency virus. Proc Natl Acad Sci U S A 1987;84:8642-6.

14 Bonetti A, Weber R, Vogt MW, Wunderli W, Siegenthaler W, Lüthy R. Coinfection with human immunodeficiency virus type 1 (HIV-1) and cytomegalovirus in two intravenous drug users. Ann Intern Med 1989;111: 293-6.

5 Fauci AS. The human immunodeficiency virus: infectivity and mechanisms of pathogenesis. Science 1988;239:617-22.

16 Hubbard RL, Marsden ME, Cavanaugh E, Rachal JV, Ginzburg HM. Role of drug-abuse treatment in limiting the spread of AIDS. Rev Infect Dis 1988;10:377-84

17 Sorensen JL, Batki SL, Gibson DR, Dumontet R. Purnell S. Methadone maintenance and behavioural change in seropositive drug abusers: the San Franco PACE) Gral Hotion (PACE). In: Program and abstrats of the Vinternational conference on AIDS Montreal, 1989. Ottawa: International Development Research Centre,
1989:707. (Abstract Th.D.O.5.)

18 Kleber HF, Slobetz F, Mezritz MA, eds. Medical evaluation of longterm methadone-maintenance clients. Rockville, Maryland: National Institute on Drug Abuse, 1980.

19 Kreek MJ. Health consequences associated with the use of methadone. In: Cooper JR, Altman F, Brown BS, Czechowicz D, eds. Research on the treatment of narcotic addiction: state of the art. Rockville, Maryland: National Institute on Drug Abuse, 1983:456-82.

20 Finnegan LD. Clinical, perinatal and developmental effect of methadone. In Cooper JR, Altman F, Brown BS, Czechowicz D, eds. Research on the treatment of narcotic addiction: state of the art. Rockville, Maryland: National Institute on Drug Abuse, 1983:392-443.

(Accepted 2 October 1990)
University Respiratory

Medicine Unit, City

Hospital, Edinburgh EH10

5SB

M F Fitzpatrick, MRCPI,

clinical research fellow

T Mackay, MRCP, lecturer in medicine

N J Douglas, FRCP, senior lecturer

Department of Physiology,

University of

Witwatersrand,

Johannesburg,

South Africa

H Driver, PHD, research

officer

Correspondence to:

Dr Fitzpatrick.

BrMed F 1990;301:1365-8

\title{
Salmeterol in nocturnal asthma: a double blind, placebo controlled trial of a long acting inhaled $\beta_{2}$ agonist
}

\author{
M F Fitzpatrick, T Mackay, H Driver, N J Douglas
}

Abstract

Objective-To determine whether inhaled salmeterol, a new long acting inhaled $\beta$ adrenergic agonist, reduces nocturnal bronchoconstriction and improves sleep quality in patients with nocturnal asthma.

Design-Randomised, double blind, placebo controlled crossover study.

Setting-Hospital outpatient clinics in Edinburgh.

Subjects-Twenty clinically stable patients (13 women, seven men) with nocturnal asthma, median age 39 (range 18-60) years.

Interventions-Salmeterol $50 \mu \mathrm{g}$ and $100 \mu \mathrm{g}$ and placebo taken each morning and evening by metered dose inhaler. Rescue salbutamol inhalers were provided throughout the run in and study periods.

Main outcome measures-Improvement in nocturnal asthma as measured by peak expiratory flow rates and change in sleep quality as measured by electroencephalography.

Results-Salmeterol improved the lowest overnight peak flow rate at both $50 \mu \mathrm{g}$ (difference in median values $(95 \%$ confidence interval for difference in medians) 69 (18 to 88$) 1 / \mathrm{min}$ ) and $100 \mu \mathrm{g}$ (72 (23 to 61) $1 / \mathrm{min}$ ) doses twice daily. While taking salmeterol $50 \mu \mathrm{g}$ twice daily patients had an objective improvement in sleep quality, spending less time awake or in light sleep $(-9(-4$ to -44$) \mathrm{min})$ and more time in stage 4 sleep $(26(6-34) \mathrm{min})$.

Conclusions-Salmeterol is an effective long acting inhaled bronchodilator for patients with nocturnal asthma and at a dose of $50 \mu \mathrm{g}$ twice daily improves objective sleep quality.

\section{Introduction}

Three quarters of all asthmatic patients are woken from time to time by coughing, wheezing, and breathlessness. ${ }^{12}$ This nocturnal asthma is associated with significant sleep disturbance and increased nocturnal awakenings, ${ }^{3.5}$ and often these symptoms form the patient's main complaint. Hitherto no treatment has been shown to improve sleep quality in patients with nocturnal asthma.

Treatment of nocturnal bronchoconstriction has been limited by the short duration of action of conventional inhaled bronchodilators so that the bedtime dose does not produce effective bronchodilatation at the end of the night, when bronchoconstriction is usually at its most severe. ${ }^{6}$ Many asthmatic patients cannot tolerate therapeutically effective doses of sustained release oral $\beta$ agonists ${ }^{78}$ or theophylline ${ }^{9}$ which, although effective in reducing nocturnal bronchoconstriction in patients with asthma, ${ }^{7.11}$ do not produce any objective improvement in their sleep quality. ${ }^{1213}$

Salmeterol, a new inhaled $\beta$ agonist, differs from conventional $\beta$ agonists in that it produces effective bronchodilatation for 12 hours after a single inhaled dose. ${ }^{1+}$ The object of the our study was to evaluate both subjectively and objectively the effect of inhaled salmeterol on nocturnal bronchoconstriction and sleep quality in patients with nocturnal asthma.

\section{Methods}

Twenty patients with nocturnal asthma were entered into a randomised, double blind, crossover study (mean age 39 (range 18-60) years; seven men) to 
compare three inhaled treatments: $50 \mu \mathrm{g}$ and $100 \mu \mathrm{g}$ inhaled salmeterol aerosol twice daily and placebo aerosol twice daily. Nocturnal asthma was defined as an average overnight fall in peak expiratory flow rate of at least $15 \%$ in association with at least two nocturnal awakenings a week due to wheezing, coughing, or breathlessness over a two week run in period in a patient with known asthma. The mean percentage predicted peak expiratory flow rate of the patients during the run in period was $63 \%$ (SD 16\%). All $\beta_{2}$ agonists were withdrawn during the study, apart from the study doses and a rescue salbutamol metered dose inhaler that was provided. All other maintenance asthma treatment for each patient was continued at constant dosage throughout the study period (oral steroid, six patients; inhaled steroid, 19; oral aminophylline, 11; inhaled ipratropium, six; inhaled cromoglycate, three). Patients were requested to abstain from beverages containing caffeine during the study; decaffeinated coffee was supplied.

Patients kept a diary record of triplicate peak expiratory flow rates taken four times during each day and at each nocturnal awakening with a mini-Wright peak flow meter. The best of the three recorded measurements at each time was used for analysis. Morning and evening peak expiratory flow rates were recorded immediately before patients took the study inhaler. Patients recorded, each morning, the number of nocturnal wakenings caused by asthma. Morning asthma symptoms, daytime asthma symptoms, and subjective sleep quality were scored on a worsening scale from 0 to 5 . Data from the first five days of each limb of the study were not analysed to exclude possible carry over effects.

At the end of each two week study period patients spent two consecutive nights in a sleep laboratory where electroencephalography, electro-oculography, and electromyography were carried out with our standard electrode placement ${ }^{15}$ and recorded on a polygraph (Neuroscribe 18, Specialised Laboratory Equipment, Croydon) at a paper speed of $15 \mathrm{~mm} / \mathrm{s}$. The standard criteria ${ }^{16}$ were used for sleep staging. Only data from the second night on each occasion were analysed, the first night serving for acclimatisation. Each patient spent the same time in bed on all three study limbs (median $402 \mathrm{~min}$ ).

The significance of observed changes was assessed by Wilcoxon signed ranks testing with application of the Bonferroni correction for multiple comparisons.

\section{Results}

TOXICITY

One patient was withdrawn on day 1 because of palpitation caused by sinus tachycardia while taking salmeterol $100 \mu \mathrm{g}$ twice daily. Another patient withdrew from the study for social reasons. One patient who required maintenance oral prednisolone $(5 \mathrm{mg}$ per day) died in status asthmaticus in another hospital after inhaling a perfume while taking salmeterol $100 \mu \mathrm{g}$ twice daily. His salmeterol had been stopped on admission to hospital, seven hours before death. He had not received a booster dose of oral or intravenous steroid on admission. No patients reported any other side effects from taking salmeterol in either dose, despite being specifically asked about possible side effects at the end of each limb of the study.

\section{DATA ANALYSIS}

Data from 17 patients who completed all three limbs of the study and data from the first two limbs of the study in the case of the patient who died during the third limb of the study were used for analysis. Both doses of salmeterol produced significant improvements in morning and daytime asthma symptoms with fewer night time awakenings from asthma (table I). Peak flow readings at all recorded times, including the lowest recorded peak flow overnight, were significantly improved by the drug in either dose (fig 1) except for the value recorded at $10 \mathrm{pm}$, for which the improvement on the smaller dose of salmeterol did not reach significance. Overnight peak flow drop (calculated as $10 \mathrm{pm}$ peak expiratory flow rate minus lowest overnight peak expiratory flow rate and expressed as a percentage of the $10 \mathrm{pm}$ peak expiratory flow rate) was reduced by both salmeterol doses. The patients reported significant improvements in both morning and daytime asthma symptoms while taking salmeterol in either dose. There was a non-significant trend towards improve-

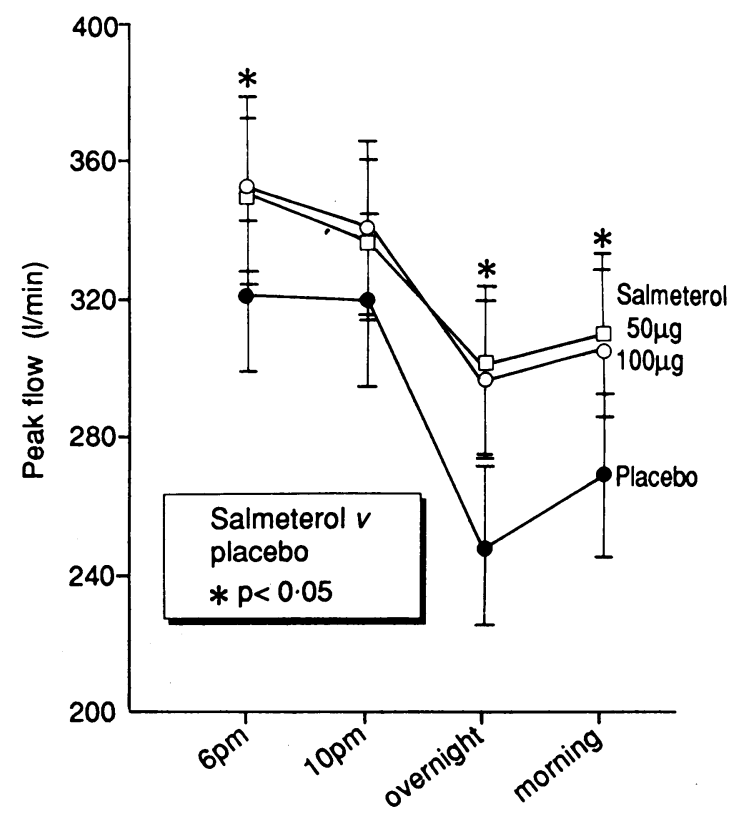

Time of day

FIG $1-$ Mean (SE) peak expiratory flow rate in 18 asthmatic patients receiving placebo $(\bullet)$ or salmeterol $50 \mu \mathrm{g}(\square)$ or $100 \mu \mathrm{g}(\mathrm{O})$ twice daily

TABLE I - Variables recorded on diary cards by 18 asthmatic patients. Numbers are medians (ranges) unless stated otherwise

\begin{tabular}{|c|c|c|c|c|c|c|c|}
\hline & \multirow[b]{2}{*}{ Placebo } & \multicolumn{2}{|c|}{ Salmeterol } & \multirow{2}{*}{$\begin{array}{c}\text { Salmeterol } 50 \mu \mathrm{g} \\
v \text { placebo }\end{array}$} & \multirow{2}{*}{$\begin{array}{c}\text { Salmeterol } 100 \mu \mathrm{g} \\
v \text { placebo }\end{array}$} & \multirow{2}{*}{$\begin{array}{l}\text { Salmeterol } 50 \mu \mathrm{g} \\
\text { minus placebo }\end{array}$} & \multirow{2}{*}{$\begin{array}{l}\text { Salmeterol } 100 \mu \mathrm{g} \\
\text { minus placebo }\end{array}$} \\
\hline & & $50 \mu \mathrm{g}$ & $100 \mu \mathrm{g}$ & & & & \\
\hline \multicolumn{7}{|l|}{ No of nocturnal awakenings caused } & $-0.3(-0.7$ to -0.2$)$ \\
\hline Subjective sleep quality $\dagger$ & $1.7(0.6-2 \cdot 9)$ & $1(0-3 \cdot 5)$ & $1 \cdot 1(0-3 \cdot 1)$ & $p>0.05$ & $p>0.05$ & $-0.3(-0.6$ to 0.1$)$ & $-0.5(-0.6$ to 0$)$ \\
\hline No of morning symptoms & $1.8(1-3)$ & $1(0-3)$ & $0.8(0-3)$ & $p<0.01$ & $\mathrm{p}<0.05$ & $-0.8(-1.2$ to -0.4$)$ & $-0.7(-0.9$ to -0.2$)$ \\
\hline No of daytime symptoms & $2 \cdot 1(1-3 \cdot 7)$ & $1 \cdot 9(0-3 \cdot 3)$ & $1 \cdot 4(0-4)$ & $\mathrm{p}<0.03$ & $\mathrm{p}<0.03$ & $-0.7(-1.1$ to -0.2$)$ & $-0.3(-0.9$ to -0.1$)$ \\
\hline \multirow{4}{*}{$\begin{array}{l}\text { Overnight peak flow drop }(1 / \mathrm{min}) \\
\text { (\% of peak flow at } 10 \mathrm{pm}) \\
\text { Lowest overnight peak flow }(\mathrm{V} / \mathrm{min}) \\
\text { No of puffs of rescue salbutamol } \\
\text { in } 24 \text { hours }\end{array}$} & & & & & & & \\
\hline & $21(0-48)$ & $9(0-42)$ & $7(0-50)$ & $\mathrm{p}<0.05$ & $\mathrm{p}<0.03$ & $-13(-18$ to -2$)$ & $-8(-15$ to -2$)$ \\
\hline & $221(120-485)$ & $290(159-454)$ & $293(109-471)$ & $\mathrm{p}<0.02$ & $\mathrm{p}<0 \cdot 01$ & $47(18$ to 88$)$ & $36(23$ to 61$)$ \\
\hline & $6 \cdot 0(0-20 \cdot 0)$ & $1.5(0-16 \cdot 0)$ & $1(0-14 \cdot 0)$ & $\mathrm{p}<0.01$ & $\mathrm{p}<0.01$ & $-1 \cdot 7(-5 \cdot 3$ to $-1 \cdot 2)$ & $-2 \cdot 2(-5 \cdot 3$ to $-1 \cdot 2)$ \\
\hline
\end{tabular}

« Medians of pair differences ( $95 \%$ confidence intervals)

† On a worsening scale of 0 to 5 . 


\begin{tabular}{|c|c|c|c|c|c|c|c|}
\hline Sleep variable & Placebo & Salmeterol $50 \mu \mathrm{g}$ & Salmeterol $100 \mu \mathrm{g}$ & $\begin{array}{l}\text { Salmeterol } 50 \mu \mathrm{g} \\
v \text { placebo }\end{array}$ & $\begin{array}{c}\text { Salmeterol } 100 \mu \mathrm{g} \\
v \text { placebo }\end{array}$ & $\begin{array}{l}\text { Salmeterol } 50 \mathrm{ug} \\
\text { minus placebo }\end{array}$ & $\begin{array}{l}\text { Salmeterol } 100 \mu \mathrm{g} \\
\text { minus placebo }\end{array}$ \\
\hline Total time spent awake at night $(\mathrm{min})$ & $53(8-165)$ & $40(8-162)$ & $37(4-196)$ & 0.06 & NS & $-14(-37$ to -2$)$ & $-10(-36$ to 9$)$ \\
\hline $\begin{array}{l}\text { Total wakefulness after sleep } \\
\text { onset }(\min ) \\
\text { Total time }(\min ) \text { : }\end{array}$ & $45(1-153)$ & $25(0-140)$ & $18(2-183)$ & $<0.04$ & NS & $-11(-36$ to -3$)$ & $-6(-31$ to 7$)$ \\
\hline $\begin{array}{l}\text { Total time }(\min ): \\
\text { Awake or stage } 1 \text { sleep } \\
\text { Stage } 2 \text { sleep } \\
\text { Stage } 3 \text { sleep } \\
\text { Stage } 4 \text { sleep } \\
\text { REM sleep } \\
\text { Sleep efficiency }(\%)\end{array}$ & $\begin{array}{l}83(18-218) \\
143(88-196) \\
27(4-45) \\
60(19-111) \\
67(25-120) \\
86(63-98)\end{array}$ & $\begin{array}{l}67(22-187) \\
146(52-184) \\
33(20-50) \\
85(41-114) \\
77(12-122) \\
91(58-98)\end{array}$ & $\begin{array}{l}58(19-223) \\
138(57-214) \\
35(17-66) \\
56(26-111) \\
80(18-114) \\
90(48-99)\end{array}$ & $\begin{array}{l}<0 \cdot 04 \\
\text { NS } \\
\text { NS } \\
<0 \cdot 02 \\
\text { NS } \\
\text { NS }\end{array}$ & $\begin{array}{l}\text { NS } \\
\text { NS } \\
\text { NS } \\
\text { NS } \\
\text { NS } \\
\text { NS }\end{array}$ & $\begin{array}{l}-26(-44 \text { to }-4) \\
-61(-31 \text { to } 20) \\
3(-2 \text { to } 10) \\
19(6 \text { to } 34) \\
5(-7 \text { to } 16) \\
3(0 \text { to } 9)\end{array}$ & $\begin{array}{c}-14(-36 \text { to } 7) \\
-8(-22 \text { to } 11) \\
10(-3 \text { to } 15) \\
4(-15 \text { to } 10) \\
12(-7 \text { to } 25) \\
3(-3 \text { to } 9)\end{array}$ \\
\hline
\end{tabular}

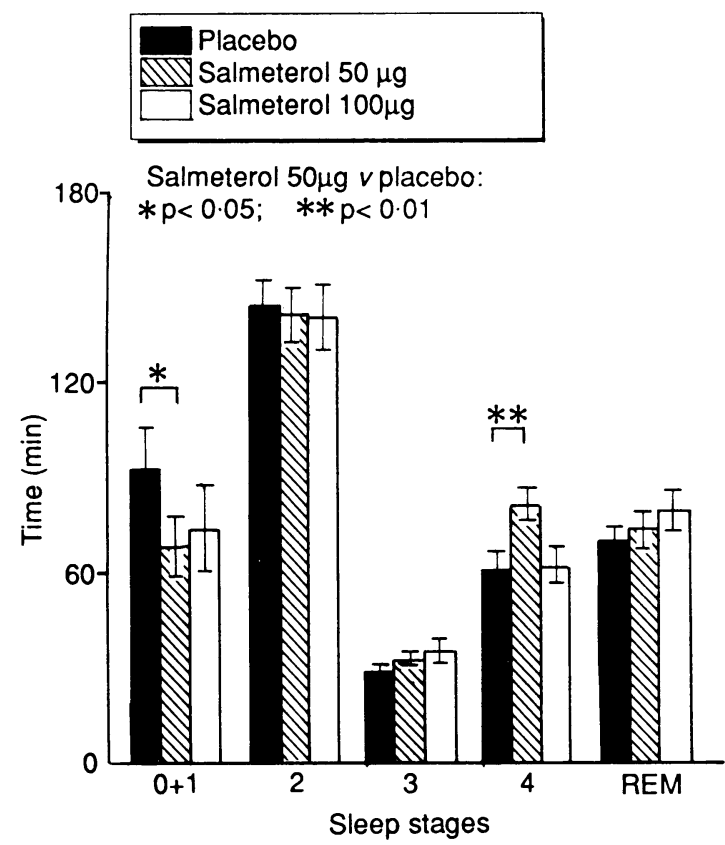

FIG 2-Mean (SE) time spent in each sleep stage by 18 asthmatic patients receiving placebo or salmeterol $50 \mu \mathrm{g}$ or $100 \mu \mathrm{g}$ twice daily. REM sleep= rapid eye movement sleep

ment in subjective sleep quality. These improvements were achieved with a reduction in mean 24 hour rescue use of salbutamol by both $50 \mu \mathrm{g}$ and $100 \mu \mathrm{g}$ doses of salmeterol twice daily.

The objective sleep recordings showed an improvement in sleep architecture by salmeterol $50 \mu \mathrm{g}$ twice daily, though there was no significant difference in sleep architecture between salmeterol $100 \mu \mathrm{g}$ and placebo (table II). Specifically, use of salmeterol $50 \mu \mathrm{g}$ twice daily was associated with more time spent in stage 4 (deep) sleep and a reduction in time spent awake or in stage 1 (light) sleep (fig 2).

\section{Discussion}

This study shows that inhaled salmeterol reduces overnight bronchoconstriction and also improves objective sleep quality in patients with nocturnal asthma. This is the first time that an agent used in the treatment of nocturnal asthma has been shown to improve objective sleep quality. The net effect of nocturnal asthma on patients' sleep is a reduction in slow wave sleep and an increase in the time spent in wakefulness and light sleep $^{+5}$ relative to normal subjects. Salmeterol $50 \mu \mathrm{g}$ twice daily specifically improves these variables, thus tending to reverse the sleep disruption caused by nocturnal asthma. Other inhaled bronchodilators have been shown to reduce nocturnal bronchoconstriction in asthma ${ }^{17-19}$ but none has been shown to improve objective sleep quality. Salmeterol achieved a mean rise in the lowest recorded overnight peak expiratory flow rate of $21 \%$ as compared with a $16 \%$ improvement by adding both salbutamol $800 \mu \mathrm{g}$ and beclomethasone $200 \mu \mathrm{g}$ four times daily ${ }^{17}$ in a group of patients with less severe asthma who were also taking less maintenance treatment than our patients. In addition, 16 of our 18 patients showed an improvement in lowest morning peak flow rate as compared with eight of 14 treated with salbutamol and beclomethasone and only nine of 18 patients treated with once nightly oxitropium. ${ }^{18}$ The fact that a small overnight drop in peak expiratory flow rates persisted during treatment with both doses of salmeterol is consistent with the belief that other, non-adrenergic, mechanisms are also involved in nocturnal asthma..$^{20}$

Oral bronchodilators, although effective in reducing nocturnal bronchoconstriction, have differing effects on sleep quality in asthma. Oral $\beta$ agonists did not significantly change sleep architecture in patients with asthma, ${ }^{12}$ whereas sustained release theophylline is associated with significant sleep disruption. ${ }^{1321}$ This may prove to be an important consideration in treating nocturnal asthma as sleep deprivation impairs daytime cognitive performance, ${ }^{22-24}$ and we have recently shown that adults with nocturnal asthma have impaired daytime cognitive performance when compared with normal subjects matched for age and intellect. ${ }^{2}$ Furthermore, theophylline has been shown to adversely affect learning, psychological performance, and behaviour in schoolchildren with asthma. ${ }^{26-29}$

Although salmeterol $100 \mu \mathrm{g}$ twice daily was as effective a bronchodilator as salmeterol $50 \mu \mathrm{g}$ in our study, it did not improve sleep quality whereas the lower dose did. We think that this is unlikely to be a chance finding as these results were consistent through several different sleep variables tested in each group. It seems likely that the higher dose of salmeterol may have caused some degree of central nervous system stimulation, which offset the potential benefit derived from its bronchodilator action. The lipophilic side chain of the compound may allow it to cross the blood-brain barrier; however, quantitative whole body autoradiography in rats suggests that only a small proportion of a salmeterol dose crosses this barrier (I Skidmore, personal communication).

Although salmeterol improved peak expiratory flow measurements; reduced asthma symptoms on waking and during the day; reduced the 24 hour requirement for rescue use of salbutamol; reduced the number of awakenings at night due to asthma; and improved objective sleep quality, there was no significant change in nocturnal use of salbutamol in patients taking $50 \mu \mathrm{g}$ of the drug twice daily $(\mathrm{p}=0 \cdot 15)$. This probably results from relatively low nocturnal use of salbutamol in the patients studied (see table II) as they had to be able to discontinue oral $\beta$ agonists to qualify for admission and be well enough to manage for two weeks on placebo. However, a significant reduction in nocturnal use of salbutamol was noted with the higher dose of salmeterol $(\mathrm{p}<0 \cdot 01)$.

Little is known about the mechanism by which salmeterol exerts its prolonged $\beta_{2}$ adrenergic agonist activity, but it is not through irreversible binding to $\beta$ 
adrenoreceptors as its action can readily be reversed with conventional $\beta$ blockers. Utilisation of a lipophilic domain in the area around the $\beta$ receptor may lead to exoreceptor binding, which would then localise the drug near $\beta$ adrenoreceptors. ${ }^{30}$

We conclude that inhaled salmeterol is an effective treatment for nocturnal asthma at both 50 and $100 \mu \mathrm{g}$ twice daily, and that the $50 \mu \mathrm{g}$ dose also significantly improves objective sleep quality. Comparison of the efficacies of salmeterol and theophylline in treating nocturnal asthma is an important next step in determining the optimal treatment for asthmatic patients.

We thank Glaxo Group Research Limited for financial assistance; Miss Aileen Stuart, clinical research scientist, Glaxo Group Research Limiteci, for technical help; and Dr James Palmer, director of respiratory division, Glaxo Group Research Limited, for comments on the manuscript.

I Turner-Warwick M. Epidemiology of nocturnal asthma. Am $\mathcal{F}$ Med 1988;85 (suppl lB):6-8

2 Connolly CK. Diurnal rhythms in airway obstruction. Br $f$ Dis Ches 1979;73:357-66.

3 Montplaisir J, Walsh J, Malo JL. Nocturnal asthma: features of attacks sleep and breathing patterns. Am Rev Respir Dis 1982;125:18-22.

4 Kales A, Beall GN, Bajor GF, Jacobson A, Kales JD. Sleep studies in asthmatic adults: relationship of attacks to sleep stage and time of night. f Allergy 1968;41:164-73.

5 Kales A, Kales JD, Sly RM, Scharf MB, Tjiauw-Ling Tan, Preston TA. Sleep patterns of asthmatic children: all-night electroencephalographic studies. f Allergy Clin Immunol 1970;46:300-8.

6 Douglas NJ Nocturnal asthma. O f Med 1989;71:279-89.

6 Douglas NJ. Nocturnal asthma. Qf Med 1989;71:279-89. and aminophylline in nocturnal asthma: relation of overnight changes in and aminophylline in nocturnal asthma: relation of overnight
lung function and plasma drug levels. Thorax 1980;35:526-30.

8 Milledge JS, Morris J. A comparison of slow release salbutamol with slow release aminophylline in nocturnal asthma. F Int Med Res 1979;7(supp 1): $106-10$.

9 Davies PDO, Fennerty AG, Benfield GFA, Parrish RW, Campbell IA. Twice daily slow-release theophylline versus placebo for "morning dipping" in asthma. Br f Clin Pharmacol 1984; 17:335-40.

10 Barnes PJ, Neville L, Greening AP, Timmers J, Poole GW. Single-dose slowrelease aminophylline at night prevents nocturnal asthma. Lancet 1982; 299-301.

11 Heins $M$, Kurtin L, Oellerich M, Maes R, Sybrecht GW. Nocturnal asthma: slow-release terbutaline versus slow-release theophylline therapy. Eur Respir J 1988;1:306-10

12 Stewart IC, Rhind GB, Power JT, Flenley DC, Douglas NJ. Effects of sustained release terbutaline on symptoms and sleep quality in patients with nocturnal asthma. Thorox 1987:42:797-800.

13 Rhind GB, Connaughton JJ, McFie J, Douglas NJ, Flenley DC. Sustained release choline theophyllinate in nocturnal asthma. BMY 1985;291:1605-8.

14 Ullman A, Svedmyr N. Salmeterol, a new long acting inhaled beta 2 adrenoreceptor agonist: comparison with salbutamol in adult asthmatic patients. Thorax 1988;43:674-8.

15 Catterall JR, Douglas NJ, Calverly PMA, et al. Irregular breathing and hypoxaemia during sleep in chronic stable asthma. Lancet 1982;i:301-4

16 Rechischaffen A, Kales A. Manual of standardised terminolagy, techniques and scoring system for sleep stage of human subjects. Washington DC: Public Health Service, US Government Printing Office, 1968.

17 Horn CR, Clark TJH, Cochrane GM. Inhaled therapy reduces morning dips in asthma. Lancet $1984 ; \mathrm{i}: 1143-5$.

$18 \mathrm{Coe} \mathrm{CI}, \mathrm{Barnes} \mathrm{PJ}$. Reduction of nocturnal asthma by an inhaled anticholinergic drug. Chest 1986;90:485-8.

19 Carpentiere G, Marino S, Castello F. Effects of inhaled fenoterol on the circadian rhythm of expiratory flow in allergic bronchial asthma. Chest 1983;83:211-4.

20 Morrison JF, Pearson SB, Dean HG. Parasympathetic nervous system in nocturnal asthma. $B M \mathcal{F} 1988 ; 296: 1427-9$.

21 Rall TW. Central nervous system stimulants: the methylxanthines. In: Gilman AG, Goodman LS, Rall TW, Murad F, eds. The pharmacological basis of therapeutics. New York: MacMillan, 1985:589-603.

22 Friedman RC, Bigger JT, Kornfield DS. The intern and sleep loss. $N$ Engl 7 Med 1971;285:201-3.

23 Williams HL, Lubin A, Goodnow JJ. Impaired performance with acute sleep loss. Psychological Monographs 1959;73:1-26.

24 Glenville $M$, Broughton R, Wing AM, Wilkinson RT. Effects of sleep deprivation on short duration performance measures compared to the Wilkinson auditory vigilance task. Sleep 1978;1:169-76.

25 Fitzpatrick MF, Cheshire K, Whyte KF, Deary I, Shapiro CM, Douglas NJ. Sleep quality and daytime cognitive performance in nocturnal asthma [Abstract]. Thorax 1990;45:338P.

26 Furukawa CT, Shapiro GG, Bierman CW, Kraemer MJ, Ward DJ, Pierson WE. A double-blind study comparing the effectiveness of cromolyn sodium and sustained release theophylline in childhood asthma. Pediatrics 1984;74: and sus.

27 Springer C, Goldenberg B, Ben Dov I, Godfrey S. Clinical, physiologic, and psychologic comparison of treatment by cromolyn or theophylline in psychologic comparison of treatment by cromolyn or

28 Rachelefsky GS, Wo J, Adelson J, et al. Behavior abnormalities and poor school performance due to oral theophylline use. Pediatrics 1986;78:1133-8. 29 Rappaport L, Coffman H, Guare R, Fenton T, DeGraw C, Twarog F. Effects of theophylline on behaviour and learning in children with asthma. Am $\mathcal{J} D i$ Child 1989;143:368-72.

30 Bradshaw J, Brittain RT, Coleman RA, et al. The design of salmeterol, a long acting selective beta 2 adrenoreceptor agonist [Abstract]. Br J Pharm 1987;92(suppl):590P.

(Accepted I November 1990)

\section{"Vanishing" of vertebra in a patient with sickle cell haemoglobinopathy}

\section{J O Ozoh, M A C Onuigbo, N Nwankwo, S O Ukabam, B C Umerah, C C Emeruwa}

\section{University of Nigeria Teaching Hospital, P M B 01280, Enugu, Nigeria J O Ozoh, FMCR, consultant radiologist \\ M A C Onuigbo, FWACP, consultant physician and nephrologist \\ $\mathrm{N}$ Nwankwo, $\mathrm{MB}$, senior registrar \\ S O Ukabam, MRCP, consultant physician and gastroenterologist B C Umerah, FRCR, professor of radiology \\ C C Emeruwa, $\mathrm{MB}$, intern}

Correspondence to: $\mathrm{Dr}$ Ozoh.

$\operatorname{BrMed} \mathcal{F} 1990 ; 301: 1368-9$
Sickle cell haemoglobinopathy is common in Nigeria, affecting $2-3 \%$ of children. ${ }^{12}$ There have been extensive reviews of radiology in patients with sickle cell haemoglobinopathy in Nigeria. ${ }^{3}$ Common radiological features in the spine include osteoporosis, osteolytic foci, biconvexity of the intervertebral disc spaces, and flattening of the vertebral bodies. To our knowledge the "vanishing" of a vertebral body has not been reported before in such patients.

\section{Case report}

A 15 year old Nigerian boy presented in July 1990 with a two year history of a swelling in the lower back. $\mathrm{He}$ had had several episodes of recurring ill health consisting of fever, bone pains, and occasional jaundice. $\mathrm{He}$ had also felt a mass in the left upper quadrant for more than 10 years. Two years earlier he had developed a painful swelling in the lower back, which increased in size over several weeks. This was associated with constipation and total loss of power in both legs. He had received orthodox medical and traditional medical consultations and had been bedridden for three months. After admission to hospital, and treatment with oral paracetamol, pethidine injections, oral haematinics, and topical massages with methyl salicylate and other antirheumatic liniments he had gradually recovered use of both legs. There was no history of contact with a patient with tuberculosis, and he had no other features referable to tuberculosis; he had never been treated with antituberculous drugs.

On physical examination at presentation the patient was pale and mildly jaundiced with prognathism and prominent maxillary bones. His anterior abdominal wall showed numerous scarification marks. There was hepatosplenomegaly. The spine showed prominent gibbous at L3 level, with a slight tilt to the right. At this level there was a non-tender bony mass of $5 \mathrm{~cm} \times 3 \mathrm{~cm}$ in the midline. The overlying skin showed three healed pressure ulcers, the right leg was weak (power 4/5), and his gait indicated slight scoliosis to the right and a slight limp of the right foot. The result of the straight leg raising test was positive for the right leg at $60^{\circ}$. The right hamstring muscles were tender to palpation. Sensation to touch and pain was intact. There was a left lateral malleolar ulcer, which was healing with paper thin re-epithelialisation.

Laboratory investigations disclosed anaemia (haemoglobin $87 \mathrm{~g} / \mathrm{l}$ ), an erythrocyte sedimentation rate of $113 \mathrm{~mm}$ in the first hour, genotype SS, and a Mantoux test result of $10 \mathrm{~mm}$. Results of liver function tests and serum electrolyte, urea, and creatinine concentrations were normal. Chest and skull radiographs were normal except for coarse trabeculation of the ribs. Plain abdominal radiographs showed multiple faceted gall stones. Spinal radiographs showed diffusely generalised osteoporosis, trabeculation, and pencil 